\title{
The Study of Americanisation
}

\section{after German Reunification:}

\section{Institutional Transfer, Popular}

\section{Culture and the East}

\author{
A X E L R. S C H ÄFER
}

Anselm Doering-Manteuffel, Wie westlich sind die Deutschen? Amerikanisierung und Westernisierung im 20. Jahrhundert (Göttingen: Vandenhoeck \& Ruprecht, I999), I60 pp., pb., € $€_{\mathrm{IO}}$.90, ISBN 3-525-34017-6.

Alf Lüdtke, Inge Marssolek, and Adelheid von Saldern, eds., Amerikanisierung: Traum und Alptraum im Deutschland des 20. Jahrhunderts, Transatlantische historische Studien 6 (Stuttgart: Franz Steiner Verlag, I996), 3 I7 pp., hb., €36.00, ISBN 3-515-06952-6.

Heide Fehrenbach and Uta G. Poiger, eds., Transactions, Transgressions, Transformations: American Culture in Western Europe and Japan (New York: Berghahn Books, 2000), $25^{8}$ pp., pb., \$24.00, ISBN I-57I 8 I-I08-7.

Uta G. Poiger, Jazz, Rock, and Rebels: Cold War Politics and American Culture in a Divided Germany, Studies on the History of Society and Culture 35 (Berkeley: University of California Press, 2000), 333 pp., pb., \$50.00, ISBN 0-520-2 I I39-I.

Wade Jacoby, Imitation and Politics: Redesigning Modern Germany (Ithaca: Cornell University Press, 2000), 226 pp., hb., £49.95, ISBN o-8oI4-3438-6.

Throughout the twentieth century, European scholars have connected their hopes, fears and expectations to powerful images of America, using evocative terms such as Fordism, coca-colonisation, the open society and repressive tolerance. During the past few decades, however, a major shift has taken place in the field of research, which more or less fittingly uses 'Americanisation' to describe the transnational impact of US economic, political and cultural power. Largely as a result of the emergence of cultural history and the linguistic turn many scholars no longer tell the story of Americanisation in terms of totalising theories, such as modernisation or cultural imperialism. ${ }^{1}$ Instead, the focus has shifted to historical agents within the host countries who adopt, transform or reject American practices in order to pursue

1 For a defence of modernisation theory see, for example, Peter Duignan and L. H. Gann, The Rebirth of the West: The Americanization of the Democratic World (Cambridge, MA: Blackwell, I992). For an example of the use of cultural imperialism as a framework see Herbert I. Schiller, Mass Communications and American Empire (Boulder: Westview Press, I992). 
their own domestic cultural and political agendas. Contemporary scholarship on Americanisation studies the process of transfer as part of a renegotiation of cultural boundaries and political power that involves both indigenous players and outside interference. Such scholarship frequently argues that Americanisation has little to do with the United States, except as an image, a projection or an icon, whose meaning is produced in the discourses and conflicts of the borrowing culture.

The books reviewed here share this approach to varying degrees, whether they discuss adolescents using American music and fashion to challenge established race and gender hierarchies, examine cultural conservatives adopting US organisational styles, or study union leaders co-operating with US occupation officials to ward off more radical demands for social change. This comes as a surprise, considering the variety of disciplinary backgrounds of the authors, who include political scientists, cultural historians, and literary scholars, and the wide range of research subjects, such as East German work brigades, pulp fiction, industrial policy, and rock 'n' roll. In spite of this diversity, the books share the view that a closer look at the agency of historical actors and the shifting meanings in the transfer process are the key to understanding Americanisation. They offer new insights into this process and sketch out fields of future research.

Anselm Doering-Manteuffel's book provides a succinct overview of the intertwined processes of Americanisation and Westernisation. The author defines Americanisation as the adoption of institutions, practices and symbols associated with 'America', and Westernisation as the emergence of a shared system of norms and values in the transatlantic world. Westernisation is thus the ideological underpinning that ensures that the process of Americanisation leads to a common transatlantic political and economic outlook and is not confined to US methods of production. Doering-Manteuffel systematically examines the interaction of US agencies and German postwar politics in the areas of economic reconstruction, constitutional order, social policy, the media and education. He also summarises the findings of a number of research projects undertaken under his guidance in the I990s. Although the book focuses exclusively on West Germany, it is a perceptive overview of the topic, accessible to a broader audience, yet useful for academic specialists. It is a balanced and sympathetic treatment that provides a thorough account despite its brevity. DoeringManteuffel locates the meaning of Americanisation in the transatlantic convergence in economic, political and social norms and values, rather than in the imposition of US practices on Europe. Though he never explicitly answers the question of the book title, 'How Western are the Germans?', he indicates that Westernisation - understood as the emergence of the postwar social-liberal transatlantic policy consensus - is more embedded in German society today than it is in the United States.

Alf Lüdtke, Inge Marssolek, and Adelheid von Saldern's edited volume is a comprehensive collection of essays on the subject. The book is divided into four sections, which reflect what the authors see as the main trajectories of the processes of adaptation and reformulation of 'America' in Germany. Part One looks at the importation of American techniques of industrial mass production, rationalisation and labour relations after the First World War. Part Two explores the way in which images 
of the United States were turned into arguments in German political discourses. Divergent interpretations of Americanisation are the centre of the third part of the book, while the final part focuses exclusively on the post-I945 period.

For the most part the volume displays both a conceptual and a qualitative cohesion that is often missing in essay collections. The introduction in particular ties together the various contributions and outlines the rationale for the volume. Most importantly, the book depicts conceptualisations of the United States as part and parcel of inner-German conflicts and contestations about cultural expression and political control.

The title of the second collection of essays, edited by Heide Fehrenbach and Uta Poiger, suggests a welcome broadening of the scope of the discussion of Americanisation. The volume focuses on the icons, goods and symbols of US culture as active ingredients in the continuing negotiation and delineation of gender, class, race, ethnic and generational differences within the host cultures. It probes the way in which US culture is employed in the articulation of challenges to established cultural norms and practices. The first section stresses the historical dimension of Americanisation and anti-Americanism. Section two explores the ways in which responses to US culture were used to define national identity. Section three takes a closer look at American music and its adaptations abroad. The last section scrutinises assumptions inherent in the distinction between 'indigenous' and 'American'.

The book offers many suggestions for future explorations into the transnational analysis of Americanisation, but it also displays some of the problems typical of conference volumes. While general themes and organising principles emerge, the contributions vary greatly in quality and scope. The articles on Japan, while intriguing, are not well integrated into the volume, due to the lack of a conceptual framework and a systematic comparative analysis. In addition, Britain is noticeably missing from this book on US culture in western Europe.

In her monograph, Uta G. Poiger examines youth culture in both parts of Germany after the war and explores its adoption of US music, films and fashion as a means of challenging mainstream norms. She also studies official attempts to control the alleged cultural threats emanating from the recourse of youth to this culture. Poiger maintains that the debates over US cultural influences were an integral part of the postwar cultural renegotiation of gender, generational and political relations. In contrast to many political historians, she underscores the similarities between the cultural policies in both East and West Germany after the war, which were frequently grounded in antisemitic, racist and gendered views of US culture inherited from the discourses of Weimar and the Third Reich. However, the paths of the two Germanies began to diverge in the late I950s. While the East Germans continued to crack down on cultural styles associated with the United States, West German authorities began to accommodate and integrate US cultural expressions into the liberal order and to employ them as Cold War weapons.

The book is well researched and richly documented, and draws upon newly opened archives in East Germany. In particular, the focus on cultural history and on the way in which East and West Germany constructed their societies in relationship 
to each other is insightful and perceptive. Nonetheless, there are problems that mar unnecessarily the book's approach. For example, the author's claim that I950s youth culture constituted a political challenge is undermined by the fact that her interviewees do not acknowledge as political their resistance to gender, racial and sexual norms (p. 206). Likewise, Poiger considers a West German commentator's description of adolescent youth gangs as a 'motorbike SA' sufficient proof that he links Nazism and homosexuality and indicts young rebels as sexual deviants (p. 96). These specific problems also point to larger issues, which are discussed below.

Finally, Wade Jacoby approaches Americanisation from a political science angle. He maintains that imitation and transfer studies must focus on the demands and capacities of the borrowing society. For a proper assessment of the meaning of transfer Jacoby contends that it is necessary to understand the different functions, images and political relations that sustain imported policies in the host country. Neither path-dependency nor macroeconomic circumstances can adequately explain the transfer process. The author presents four case studies of industrial relations and secondary education drawn from the postwar era and post-unification Germany. However, while the US effort to transform industrial relations after I945 was quite successful, the attempt to reform the German education system failed. By the same token, the post-I990 West German attempt to impose industrial relations failed, while educational reforms in the East were more successful. Jacoby concludes that, for transfer to succeed, institutional change must be pulled in by local groups that 'sponsor' the import. Effective transfer works best when there are indigenous minority traditions that embrace the same goals.

The book is a thorough and detailed account that provides a systematic look at institutional transfer and raises important methodological issues. Jacoby's analysis of the postwar years is generally more lucid and perceptive than his analysis of post-I990 Germany, though this is largely due to the lack of existing research and the problem of assessing the transfer process after only eleven years.

\section{Americanisation before the Second World War}

While the majority of the books focus on the post-I945 setting, some explore Americanisation during the first part of the century. Mary Nolan's essay in Transactions (pp. 3-25) provides a good discussion of the shift in European imagery from the idealisation of the pre-industrial American West to a concept of the United States as the embodiment of industrial modernity. Likewise, Doering-Manteuffel summarises the rise of the United States in German political consciousness in the period after the First World War, when it emerged as the model of the society of the future, and became the screen upon which both European fears and hopes were projected. Though European observers criticised mass consumerism, alienated labour and cultural decline, US-style Taylorist rationalisation and Fordist economics were increasingly seen as a means for overcoming the rigid class division and conflicts of German society. 
Throughout the interwar years, Europeans harboured ambivalent feelings toward both US cultural styles and economic models. In Amerikanisierung Adelheid von Saldern provides a perceptive overview of the debate about Americanisation as an attempt by the economically weakened and culturally embattled educated middle classes to retain their cultural dominance in the post-I9I8 period (pp. 213-44). Constructing the United States as the culturally deficient other thus became a mainstay of German cultural self-assertion. In the same volume, Miriam Hansen presents a convincing analysis of Siegfried Krakauer's construction of a link between modernity and socialism and between cultural and social transformation (pp. I6I-98). Krakauer located the political potential of modernity and mass culture in challenges to established social and sexual divisions in society. However, when he realised that mass culture encouraged escapism, he became increasingly sceptical about its emancipating potential and recognised that it reasserted tradition, authority and established social norms. Eva Rosenhaft explores the connection between women's emancipation and US-style consumption, visuality and mass society (pp. II9-43). She sees the rise of mass society and the mass media as a way for women to claim political power, and interprets the criticism of consumer culture as an attempt to reassert masculinity. At the same time the Third Reich successfully used images of femininity and consumption to reproduce its own repressive stability. Inge Marssolek focuses on the images of the United States in German pulp fiction (pp. I44-60). Applying the theoretical framework outlined by popular culture studies, she looks for strategies of resistance and subversion directed against the increasing discipline in modern industrial society. However, many of the images in pulp fiction were also compatible with Nazi ideology. Ursula Nienhaus studies the adaptation of US models of rationalisation in business and government offices in the I920s (pp. 67-77). The largely female workforce resented the incessant measuring, obsessive monitoring and increasing workload that came with Taylorism, but welcomed the modernising influences that afforded women more work opportunities and economic independence. Finally, efforts to rationalise domestic work are at the center of Michael Wildt's contribution (pp. 78-95). While modern interior design and appliances introduced factory-like efficiency to kitchens, women often resented the notion of reducing kitchen work to mechanical functions. Appliances frequently ended up not saving any time, and preparing proper meals required experience and hands-on involvement, rather than mechanisation.

One of the periods that needs more attention from scholars of cultural transfer is the Third Reich. Some of the essays suggest that studying the connections between authoritarian regimes and US cultural imports challenges the concept of Americanisation as democratic modernisation. Taking a closer look at industrial policy during the Third Reich, Rüdiger Hachtmann argues that the Nazis combined race ideology, industrial discipline and the promise of consumer goods with US methods of rationalised production (pp. 37-66). In his intriguing essay Hachtmann contends that Fordism and Taylorism were not postwar adoptions, but an integral part of the co-operation between German and US business during the Nazi period, symbolised by the sight of Goebbels making hate-filled speeches in the Sportpalast 
beneath advertisements enticing the audience to 'Drink Coca-Cola'. Alf Lüdtke's sketchy but thought-provoking essay in the same volume suggests that prewar images of technological progress in both the mainstream and the left-wing press propagated a vision of overcoming class division and social strife through streamlined industrial power (pp. I99-2 I0). However, while the US context linked streamlined technology to the politics of productivity after the war, Nazi Germany increasingly pictured death and destruction as part of the inherent logic and aesthetic dimension of industrial progress.

\section{The United States and postwar Germany I: politics and institutional transfer}

In the postwar era, perceptions of the United States as the frame of reference were supplemented by its presence in Europe. The United States was no longer simply a far-away land on to which Europeans could project their fears and hopes. It was a major military, political and economic player in European affairs. In the postwar context, the term 'Americanisation' thus describes the transatlantic convergence in political systems, economic structures and normative orientations. What is particularly intriguing is that the New Deal order in the United States is as important for understanding postwar European political and institutional reconstruction as the US physical presence in Europe. New Deal policies and wartime government intervention had reshaped the United States in ways that made its institutions more compatible with Europe and facilitated the transfer process, which came to fruition in Cold War liberalism. Americanisation is thus not solely associated with free enterprise, laissez-faire and acquisitive individualism, but also with macroeconomic planning, a basic welfare state and Keynesian economic policies. Rather than just exploring the missed opportunity for democratic socialism in Germany after the war, scholars also need to consider the extent to which the United States was willing to support policies that limited free-market capitalism and business control. US occupation policies would have looked different if they had been based on the neo-liberal ideology that dominates the US political landscape today. This also raises the question to what extent the policy shifts in the United States and Great Britain since the I980s have undermined the postwar transatlantic policy consensus.

The significance of the New Deal legacy for European postwar reconstruction is best expressed in two studies summarised by Doering-Manteuffel. In the first, Michael Hochgeschwender analyses the Congress for Cultural Freedom (CCF), the leading association of anti-communist European intellectuals founded in 1950 and disbanded in 1967 when the financial support of the CIA was revealed (pp. 75-90). ${ }^{2}$ Hochgeschwender sees consensus liberalism, popularised and embraced by the CCF, as a fully developed ideological alternative to twentieth-century totalitarianism. $\mathrm{He}$

${ }^{2}$ See Michael Hochgeschwender, Freiheit in der Offensive? Der Kongreß für kulturelle Freiheit und die Deutschen (Munich: Oldenbourg, 1998). See also Volker Berghahn, America and the Intellectual Cold Wars in Europe: Shepard Stone between Philanthropy, Academy, and Diplomacy (Princeton: Princeton University Press, 200I). 
considers the CCF as the genuine voice of American liberals and of returning European exiles, resistance fighters and intellectuals disillusioned with communism. The CCF constituted the most effective transatlantic network of intellectuals and politicians, and included such luminaries as Raymond Aaron, Benedetto Croce, Alfred Weber, John Dewey, Upton Sinclair, Reinhold Niebuhr and Arthur Koestler. It drew its intellectual and cultural strength from the confluence of European experiences and American New Deal social thought. The goal was to overcome traditional ideological lines of division and to establish a broad, inclusive social-liberal democratic order to undercut the appeal of communism after the defeat of fascism.

In her study, Julia Angster describes a similar process of convergence among trade unionists in postwar Germany (pp. 90-IO2). ${ }^{3}$ Though many labour leaders supported industrial democracy and the nationalising of key industries, the years in exile had exposed them to the more accommodationist industrial unionism practised in the United States and Britain. The surprising interest of US unions in helping to rebuild the German labour movement can be traced back to these contacts. American consensus liberalism became the formative political experience of postwar German labour leaders. The stress on class conflict gave way to the mutual goal of labour and capital to increase productivity, stabilise the market, ensure social peace and increase consumer spending. Though sidelined in the beginning, the returning exiles kept pursuing their goals, which paid off in the late I950s when both the Social Democratic Party (SPD) and the German union movement affirmed market economics and rejected the last vestiges of Marxism.

Wade Jacoby provides substantiating evidence for this analysis. He maintains that the post-I945 Allied efforts to impose industrial relations succeeded because they engaged a significant local minority group and built upon the shared experiences of German and US union leaders. As a result, a more radical reordering of social relations along the lines of large-scale co-determination, nationalisation of industry and industrial democracy was stifled. An alliance between occupation officials and a minority of German union leaders prevented a unified and centralised union and facilitated the emergence of limited co-determination.

Additional examples of the process of transatlantic political and institutional convergence are explored in the articles by Peter Krieger in Transactions (pp. I87207) and by Paul Betts in Amerikanisierung (pp. 270-90). Krieger's illuminating essay discusses the politics behind adopting or rejecting the label 'American' in postwar German architecture. Betts examines the reimportation of Bauhaus styles into Germany after its leading architects, such as Mies van der Rohe and Walter Gropius, had revolutionised building styles in the United States during the I930s and 4os. He argues that architectural convergence became a way of cementing the Cold War partnership between West Germany and the United States. Linking the radicalism of the Bauhaus tradition to 'liberalism' and the 'international style', he suggests, was part of the reinvention of a transnational style of Western modernity.

\footnotetext{
3 See Julia Angster, 'Konsenskapitalismus und Sozialdemokratie. Zur ideellen Westorientierung der deutschen Arbeiterbewegung I945-I965', PhD thesis, Tübingen University, I999.
} 
These studies indicate that the US agenda for postwar reconstruction was based on the personnel, precepts and organisational experiences of the New Deal. Since many of the policies of the New Deal were themselves recycled from concepts that US progressives had first gleaned from Europe before the First World War, one might even speak of the Europeanisation of Europe via the reimportation of political concepts that progressives had gleaned from Europe and implemented during the New Deal. ${ }^{4}$ Measured statism, redistributionist impulses, labour-management cooperation and labour legislation were as much part of the New Deal agenda as of European left-liberal policies. As a result, groups that were traditionally politically sidelined in the United States, such as the labour unions, had a voice in US policies abroad. Nonetheless, Cold War imperatives, the wartime restoration of the image of business in the United States and the politics of productivity ended up stifling calls for more radical social transformation.

\section{The United States and postwar Germany II: culture}

Though the term Americanisation is commonly used to used to describe the process of transatlantic convergence, another meaning of the term has gained popularity in the wake of the rise of cultural history. In this definition, Americanisation denotes the subversive meanings US culture developed within the German context, and the way these challenged established race, gender and class distinctions in the postwar process of cultural reconstruction. War, defeat and occupation had undermined traditional political structures and cultural identities in Germany. This opened up opportunities for the cultural assertion of the working class and groups in society that had been frozen out of the cultural mainstream. Adoptions of US styles, norms and practices played an important role in this process. The underlying assumption of this interpretation of Americanisation is that adoptions of US culture account for the process of postwar liberation from the shackles of German high culture and repressive social norms, which in turn effected a political transformation. Nonetheless, popular culture was also frequently co-opted, and buttressed, rather than challenged, the bourgeois social order.

In the immediate postwar years, the old elites in Germany were caught in a dilemma. On the one hand they embraced political Westernisation, on the other they held on to a tradition of cultural anti-Americanism. Though Cold War politics and US military protection ultimately cemented the loyalty to the democratic state among the middle classes, as Doering-Manteuffel concludes, their anti-democratic orientation and cultural anti-Americanism survived into the early postwar era. Thomas Sauer's study, summarised in Wie westlich sind die Deutschen (pp. I02-I8) examines the Kronberger Kreis, which brought together Protestants of the anti-fascist confessing church, politicians, businessmen and journalists, who sought to adjust

\footnotetext{
${ }^{4}$ For a good discussion of this see Daniel Rodgers, Atlantic Crossings: Social Politics in a Progressive Age (Cambridge, MA: Harvard University Press, I998).
} 
postwar Protestantism to the new political order. ${ }^{5}$ Their main concern was how to reassert Protestant culture that had been weakened by the moral catastrophe, Protestantism's association with Nazi Germany and the division of Germany. The Kreis was politically close to Adenauer and supported a pro-Western orientation, but its world view was built upon a political traditionalism that embraced natural authority, social peace and a community of moral norms.

A very different way of coming to terms with the postwar order was exemplified by the conservative Springer press empire. Gudrun Kruip, whose study is also summarized in Wie westlich sind die Deutschen? (pp. I $8-26$ ), maintains that the Springer press was an example of the merger of journalistic modernism with antiliberal national-conservative political positions. ${ }^{6}$ This was personified by the Springer journalist Hans Zehrer, who came from the anti-republican prewar magazine Die Tat. By declaring reunification to be the topmost political goal, the Springer press ran counter to the main tendencies of integration into the Western alliance and a united Europe. Nonetheless, the Springer papers opposed any form of extremism and supported the social market economy.

The tension between the political turn to the West and the desire to conserve German cultural norms was also the backdrop for the failed attempt of US occupation policy to replace the hierarchical and authoritarian German educational system with a US-style common school system. As Jacoby points out in chapter 4, this failure was rooted in the contradictions of the planning process, German bourgeois and religious resistance, and the refusal of the Americans to co-operate with left-wing German supporters of educational reform. School reform thus replicated the famed failure to reform the civil service. ${ }^{7}$

Two further essays contribute to the study of the tension between political Westernisation and cultural conservatism. In Transactions, Heide Fehrenbach looks at postwar German films (pp. 8I-IO8). She sees the resurgence of German cinematic forms and contents in the postwar era as a result of intense uneasiness about the disruptive impact of Hollywood on elite morals and norms throughout the I950s. Axel Schildt's short article on the America Houses in Amerikanisierung discusses attempts to popularize US high culture (pp. 257-69) in order to appeal to the politically willing but culturally recalcitrant elites. The wide range of activities of the Amerikahäuser included lectures on US literature, exhibitions of modern architecture, discussions on US art, and talks by German émigré academics. In the long run, however, the appeal of high culture was overshadowed by the enticements

${ }^{5}$ See Thomas Sauer, Westorientierung im deutschen Protestantismus? Vorstellungen und Tätigkeit des Kronberger Kreises (Munich: Oldenbourg, I999).

${ }^{6}$ Gudrun Kruip, Das 'Welt'- 'Bild' des Axel Springer Verlags. Journalismus zwischen westlichen Werten und deutschen Denktraditionen (Munich: Oldenbourg, I999).

7 On this failure see Udo Wengst, Berufsbeamtentum zwischen Reform und Tradition. Beamtengesetzgebung in der Gründungsphase der Bundesrepublik Deutschland (Düsseldorf: Droste, I988); and Curt Garner, 'Schlußfolgerungen aus der Vergangenheit? Die Auseinandersetzungen um die Zukunft des deutschen Berufsbeamtentums nach dem Ende des Zweiten Weltkrieges', in Hans-Erich Volkmann, ed., Ende des Dritten Reiches - Ende des Zweiten Weltkrieges. Eine perspektivische Rückschau 1933-1945 (Munich: Piper, I995). 
of US popular culture, which was much more successful in transforming German society.

The very ambivalence of the old elites, weakened and shaken by the catastrophe of war and genocide, and torn between reasserting traditional cultural norms and embracing Westernisation, was instrumental in this process of cultural transformation. By defining US culture as threatening on the one hand, yet seeking to consolidate the integration of Germany into the Western alliance on the other, the host culture opened up opportunities for working- and middle-class youths to employ US cultural styles to challenge the established moral norms and social customs of German society. Kaspar Maase's engaging essay in Amerikanisierung (pp. 29I-3I3) argues that the Americanisation of lifestyles tilted the symbolic power balance toward the lower middle and working classes. Maase asserts that the underprivileged used expressions of popular culture to legitimate their values and to attack the high culture regime. $\mathrm{He}$ calls these challenges to bourgeois dress codes, behavioural norms, moral codes, and gender delineations 'Americanisation from below'. According to Maase, the outcome was ambiguous. On the one hand, adopting US cultural styles lent legitimacy to genuine lower class cultural expressions and provided a measure of self-respect against bourgeois denigration. On the other hand, consumerism and popular culture became integrated into bourgeois capitalism and provided it with new legitimacy and cultural power. In the end, the cultural reconfiguration of class boundaries cemented the Western orientation of Germany, but also reduced authoritarian stratification and encouraged democratic habits.

Uta Poiger suggests a similar interpretation in Jazz, Rock, and Rebels. Like Maase, she maintains that adolescent adoptions of US styles challenged the postwar social order in both Germanies. However, she sees the transformation into non-threatening and depoliticised cultural styles as the result of either outright repression in the East, which ultimately failed, or more subtle integration in the West, which did not address the underlying political content of popular culture. According to Poiger, liberal social scientists in the West, such as Helmut Schelsky, redefined adolescent behaviour as apolitical and as a natural expression of the process of growing up. ${ }^{8}$ Schelsky and others regarded youth culture as the expression of a sceptical generation that sought consumer pleasure rather than political ideologies, in contrast to the highly politicised youth of the Weimar period and the Third Reich. These interpretations, Poiger maintains, severed the link between youth rebellion and proto-fascism that had been the mainstay of the conservative rejection of popular culture. American popular styles, along with the replacement of old elites and the emergence of a new political consensus, were thus reinterpreted as a force pointing towards the emergence of democratic forms and as a useful instrument in the cultural Cold War.

Though the popular-culture approach is useful in showing how I950s workingclass adolescents used American music and fashion to break through culturally sanctioned subordination, it overstates the subversive content of US-oriented youth

${ }^{8}$ See, for example, Helmut Schelsky, Die skeptische Generation. Eine Soziologie der deutschen Jugend (Düsseldorf: Diederichs, I957). 
culture. This subversive potential is primarily defined by the reactions of the authorities, rather than by the challenges to the social order embedded in popular culture. Seeing the adoption of music, fashion and styles as a radical challenge neglects the fact that the imported cultural forms themselves transported cognitive frameworks that promoted the habits and norms that underlay consumer capitalism, for example idolising celebrities, cultivating images of masculinity, seeing women as sexual objects, glorifying technology and linking self-expression to consumption. Moreover, US agencies promoted the importation of certain styles and excluded others. The fact that they promoted white rock 'n' roll musicians and movie stars, such as Bill Haley, Elvis Presley, James Dean and Marlon Brando, needs to be taken into consideration when defining US culture abroad. Similarly, the 'depoliticisation' and 'whitening' of rock 'n' roll was not just the result of liberal society pulling popular culture's fangs. It was also the result of commercial dissemination that sought to make US popular culture accessible to a wider audience and to ensure its commercial success.

Although what is mainstream in one culture can assume subcultural and subversive meanings in another, as Poiger and Maase argue, the question to what extent popular culture reaffirmed the existing social and cultural order needs to be addressed in more detail. The use of US popular styles cannot be completely divorced from the conditions of their production and their economic imperatives. Although popular culture was used by the underprivileged to legitimate their values, it also tied them to the system of consumer capitalism which neither challenged the maldistribution of wealth nor the class divide.

Another shortcoming of the focus on the liberating elements of popular culture can be found in Poiger's problematic emphasis on the close link between the Third Reich's anti-Americanism and the repressive policies of postwar German governments. As a result, she denies validity to the claim of opponents of US popular culture that fascism was grounded in part in a radicalised popular youth culture. Many contemporaries feared US-inspired popular culture not simply because of cultural anti-Americanism and the threat to social and gender norms, but because they interpreted jazz and rock 'n' roll on the basis of their understanding of fascism as the collective unleashing of repressed drives and frenzies of aggression and sexuality. Though their fears of US popular culture were unfounded, critics who saw a link between fascist popular culture and genocide had a difficult time recognising US-inspired popular culture as nonthreatening. These perceptions deserve a more sympathetic evaluation than they receive in Poiger's book. Although continuities between Nazi and postwar cultural tropes in the interpretation of US culture did exist, not all criticisms of US popular culture can be placed in this category. ${ }^{9}$

A third problem needs to be addressed. The cultural historiography of postwar Americanisation tells the story of the I950s on the basis of a narrative spelled out by

\footnotetext{
9 For a recent study on perceptions of the Third Reich in Germany in the immediate postwar years see Eike Wolgast, Die Wahrnehmung des Dritten Reiches in der unmittelbaren Nachkriegszeit (1945/1946) (Heidelberg: C. Winter, 200I).
} 
those who rebelled in the I960s. In Poiger's case, government attempts to 'control' youths and adolescent rock fans are posited against genuine expressions of cultural rebellion that 'challenge' gender and race norms. When Cold War liberals began to co-opt these cultural expressions, it was at the expense of their 'true' radical content. According to this master narrative, the insurgent movements did not recover the radical political content of cultural liberation until the I960s, when they directed their rebellion against both cultural conservatism and Cold War liberalism. In retrospect, however, the sixties movements, instigated mainly by middle-class youths, ended up adapting the moral norms and social customs of the middle classes to the requirements of consumer capitalism. One of the fascinating developments in the last thirtyodd years is how capitalism has managed to reinvent itself by fully integrating the allegedly subversive language of cultural transvaluation adopted by the insurgent movement of the sixties, while effectively marginalising their socioeconomic content. Thatcherite and Reaganite notions of consumer power in a competitive deregulated economy have become a more powerful vision for a populace thoroughly socialised into the consumerist mindset than the left's ideas of social justice and redistribution of income. This indicates that the concept of a link between cultural liberation and social change, which the insurgent movements of the sixties operated on, is flawed. In many ways the cultural Americanisation and political anti-Americanism of the I96os bourgeois insurgents did not question the social status quo, but simply inverted the cultural anti-Americanism and political Westernisation of the middle classes in the I950s.

\section{Americanisation and East Germany}

East Germany has long been terra incognita on the map of students of Americanisation, but the process of reunification has raised new questions about the postwar transfer of institutions and culture. Except for Uta Poiger, however, authors pay little attention to East Germany in these books and essays. Though Jacoby provides a detailed look at post-unification institutional transfer, his theme is not Americanisation. Only two essays in the collections deal explicitly with the US impact on East Germany. Peter Hübner's essay in Amerikanisierung on East German workers' brigades is instructive, but sketchy and conjectural when it comes to the issue of Americanisation (pp. 96I I 5). Hübner argues that the workers' brigades increasingly functioned as conduits for exchanging information on the West and the diffusion of Western cultural styles. Meanwhile, East Germany relied on outdated machinery and inefficient work organization and thus failed to 'Americanise' production. The short contribution by Ina Merkel in the same volume maintains that the demonisation of the United States in East Germany had the unintended consequence of the idealising it for many young people (pp. 245-54). Unfortunately, the essay lacks analytical depth and relies on a limited range of primary sources. It focuses more on the official image of the United States painted in a leading East German news magazine than on exploring whether and to what extent these images were used by groups in East German society to challenge the political establishment. 
Despite these shortcomings, the contributions encourage a closer look at the intriguing issue of the link between the processes of Americanisation and reunification. Three themes in particular stand out. First, Germany's postwar reconstruction became the frame of reference for the post-unification transfer of institutions. West Germans expected the East to replicate their postwar success story, forgetting that the Western situation was completely different. As Jacoby notes, the postwar economic resurgence of West Germany could take place because the country filled a niche in the world economy. In contrast, the economy of the former East Germany after unification was a competitor to the established economic capacity of the West. The only possible complementary role would have been as a site of either low-wage or high-tech production, both of which were forestalled primarily by the collapse of east European markets and the currency union (p. 39). Other differences were equally significant. Jacoby points out that after forty-five years of communism, East Germany was bereft of people with memories of democratic processes. He also suggests that East German dissidents were reformist in orientation and not as interested in fundamental social change as had been opponents of Hitler (p. I6).

One could list numerous other factors that undermine the comparability of the postwar and the post-unification settings. After the Second World War, there were at least four elements that accounted for the so-called German Wirtschaftswunder. The first was the massive influx of US money through the Marshall Plan. The second was the influx of millions of eastern refugees who had lost everything and were forced to start from scratch. The third was that money and effort went into rebuilding and modernising an industrial society, rather than managing the transition to a postindustrial one. The fourth was the guilt about war and genocide, and the sense that, after having waged the most destructive war in history and killed millions of people, it was about time that Germany did something worthwhile. What better way to achieve this than to engage in productive output without having to think too much about moral issues? As far as the former East Germany after I990 is concerned, however, only the first factor was present, the money transfer. There was no influx of population, no large-scale intermingling of peoples, no urgent need to rebuild from scratch, and no interest in reconstructing East Germany for industrial production. Likewise, there was no profound sense of guilt. East Germany was a state where anti-fascism was decreed, and, in some respect, more thoroughly practised than in the West. While most East Germans readily admit that communism was a complete economic failure, they hesitate to see it as a complete moral failure, too.

If conditions after I945 were different from those after I990, so were the processes. While the Allies after I945 used what Jacoby calls a 'functional equivalent approach', the Germans after I990 relied upon 'exact transfer'. The former was more flexible and relied more on existing social structures, whereas the latter locked everyone into a replication scenario. As Jacoby shows in his study of industrial relations (chapter 5), the genuine East German enthusiasm, massive cash flow and the availability of fully developed West German institutions could not make up for the lack of indigenous actors rooted in East German society to 'pull in' the imported structures. Instead of establishing Western-style collective wage bargaining, strong unions and unified 
business organisations, the transfer of industrial relations resulted in weak unions, the collapse of high wages, fragile employer organisations and a need for further subsidies for the east. As a result, exact transfer helped catalyse 'the largest institutional changes in industrial relations in the postwar period' (p. I33) and undercut some of the 'key conditions for its own regeneration' (p. I 40). Moreover, associating unification with postwar reconstruction hides the fact that, despite the transfer of the West German model of a social market economy, the larger global frame of economic policy has changed from Cold War capitalism to neo-liberalism. Globalisation, deregulation and free trade policies are imported into eastern Germany via the European Union, and the weaker labour market and economic structures make it easier to push through the privatisation of public services. For example, as Jacoby notes, West German firms found the obstacles to privatising utilities much less entrenched in the east than in the west (p. I42).

The second theme is that the cultural legacy of Americanisation in the West frequently conceptualised East Germany as the unreconstructed other. In the Western Cold War narrative, West Germany was neat, clean, and orderly, tried its best to appear cosmopolitan and always nodded when it came to confessing the sins of the past. East Germany, in contrast, was depicted as run-down and sinister, decreeing anti-fascism and cultivating a type of goose-stepping industrial proletarianism. Americanisation is thus turned into a foundation myth in both the leftist notion that the adaptation of US popular culture and styles was constitutive of the emancipation of West Germany from the shackles of its authoritarian past, and in the rightist argument that the embrace of liberal democracy, market economics and the transatlantic alliance accounted for the economic success of West Germany.

This became obvious when the unification of Germany came about in I990. Leftists warned of an upsurge of a new nationalism and saw eastern Germany mired in latent fascism, cultural repression and narrow-minded provincialism. Conservatives made sure that unification would not be accompanied by the assertion of a distinct eastern German identity and the survival of its institutions. However, by interpreting unification through the filter of postwar reconstruction, both sides reinforced the view that eastern Germany could only be redeemed through outside intervention. As Uta Poiger correctly claims, East German society is understood only in terms of the absence of a liberal order, which posits the West as an ideal against which the East is measured (Jazz, Rock and Rebels, p. 223). ${ }^{10}$

The third theme is that Americanisation, instead of defining the differences between East and West Germany, could be a useful category for understanding the similarities in the development of both societies after the Second World War. As Uta Poiger's volume shows, West and East German authorities had much in common when it came to defending established social and cultural norms in the postwar period, and the two political systems were constructed in relationship to each other.

\footnotetext{
${ }^{10}$ For a useful discussion of the intellectuals' perspective on unification see Jan-Werner Mueller, Another Country: German Intellectuals, Unification, and National Identity (New Haven: Yale University Press, 2000).
} 
A glance beyond the I950s shows that both Germanies continued to feed on each other. The West German welfare state tried to compete with East German socialism, and East Germany attempted to produce a socialist equivalent of Western consumer culture. What emerged was a consumerist socialism in the East and a social-liberal consumerism in the West. The first collapsed in part because it tried to satisfy the consumerist longings on the basis of socialist economic policy, whereas the latter thrived, because it satisfied socialist longings by harnessing the dynamics of consumer capitalism. East German communists constantly measured their success on the scale of capitalist production and efficiency. They even designed communist equivalents of Western consumer products, such as jeans and cola. The result was the socialisation of East Germans into the modes of consumer culture. ${ }^{11}$ This was reinforced by the West German media beaming its message to the East, the GDR's clandestine participation in the European common market, and the material promises of socialism. In the final analysis, the transfer process and the mutual construction of the two Germanies reveal that communism collapsed under the weight of its own contradictions, but also explain why life in the post-unification east in so many ways is the continuation of East Germany by other means.

\section{The transnational angle}

While German unification opened up new vistas, the study of the larger transnational dimension of Americanisation is even more promising. Transactions in particular raises this issue. In the introduction, for example, the editors call for more detailed studies of the relationship between Americanisation and decolonisation (pp. xxiv-xxv). The imperialist past, postwar French and British attempts to reassert their empires, and the calamities of decolonisation shaped the way America was interpreted in these countries. The essays in the volume suggest further fields of inquiry. David W. Ellwood looks at the historical features of anti-Americanism in Europe (pp. 26-44); Botond Bognar examines architectural history as a basis for discussing the larger cultural issues involved in the borrowing process (pp. 45-78); James Petterson sheds light on the politics and economics behind the French resistance to American cultural imports (pp. I09-23); Franco Minganti analyses the process of domesticating rock 'n' roll in Italy (pp. I48-65); Ian Condry looks at the adaptation of rap and US styles by alienated middle-class youths in Japan (pp. I66-84); Richard F. Kuisel suggests that French cinema has 'Americanised' itself, but has also retained its own cultural distinctiveness (pp. 208-23); and finally, Takayuki Tatsumi offers an engaging analysis of the cross-cultural adaptation of literary styles and the synchronicity between US and Japanese fiction, in which Western orientalist discourses are used, mimic-like, as a counter-strategy against Western orientalism (pp. 224-36).

Despite these valiant explorations into the hazy realms of transnationalism, however, the volume fails to analyse systematically the international dimension

11 A good analysis of this can be found in Stefan Wolle, Die heile Welt der Diktatur. Alltag und Herrschaft in der DDR, 1971-1989 (Berlin: Links, 1998). See also Ina Merkel, Utopie und Bedürfnis. Die Gechichte der Konsumkultur in der DDR (Cologne: Böhlau, I999). 
of Americanisation. In particular, there is little scrutiny of the way in which Americanisation shaped the rebuilding of inter-European relations after 1945. Politically, the presence of the United States redefined the way European countries related to each other. Culturally, adaptations of American styles and practices formed a basis for transnational communication for the postwar generation, which culminated in the European rebellions of the I960s. This is where scholars of Americanisation could cast their nets in the future. 